\title{
Rapid loss of phosphorus during early pedogenesis along a glacier retreat choronosequence, Gongga Mountain (SW China)
}

Yanhong Wu, Jun Zhou, Haijian Bing, Hongyang Sun, Jipeng Wang

The loss of phosphorus $(\mathrm{P})$ during the early pedogenesis stage is important at the ecosystem level, and it also plays an important role in the global P cycle. The seasonal variation of total $\mathrm{P}(\mathrm{Pt})$ and its fractions along a young soil chronosequence (Hailuogou chronosequence) on the eastern slope of Gongga Mountain, SW China, was investigated based on the modified Hedley fractionation technique to understand P loss during the early pedogenesis stage. The results showed that the mineral P (mainly apatite) was the dominant fraction of $\mathrm{Pt}$ in the $\mathrm{C}$ horizon of the soil, and the seasonal difference in Pt and its fractions was insignificant. In the A horizon, Pt concentrations decreased markedly compared with those in the $C$ horizon, and as the age of the soil increased, the inorganic $P$ (Pi) significantly decreased and the organic P (Po) prominently increased. Seasonally, the $P$ fractions exhibited various distributions in the $\mathrm{A}$ horizon. The variation of $\mathrm{Pt}$ and its fractions revealed that the $\mathrm{P}$ loss was rapid along the 120 -year soil chronosequence. The concentrations of Pt in the original minerals decreased more than $50 \%$ in the 52 years since the glacier retreated, and the depletion reached almost $80 \%$ at the 120 -year pedogenesis. The loss of $\mathrm{P}$ from the soil of the Hailuogou chronosequence was mainly attributed to weathering, plant uptake, and transport by runoff. The data obtained indicated that the glacier retreat chronosequence could be used to elucidate the fast rate of $\mathrm{P}$ loss during the early pedogenesis stage. 
1 Rapid loss of phosphorus during early pedogenesis along a glacier retreat

\title{
chronosequence, Gongga Mountain (SW China)
}

\author{
Yanhong $\mathrm{Wu}^{1}$, Jun Zhou ${ }^{1}$, Haijian Bing ${ }^{1}$, Hongyang Sun ${ }^{1}$, Jipeng Wang ${ }^{1,2}$ \\ (1 Key Laboratory of Mountain Surface Process and Ecological Regulation, Chengdu Institute of Mountain \\ Hazards and Environment, Chinese Academy of Sciences, 610041, Chengdu, China; \\ 2 University of Chinese Academy of Sciences, Chinese Academy of Sciences, 100049, Beijing, China)
}

Abstract The loss of phosphorus (P) during the early pedogenic stage is important at the ecosystem level, and it also plays an important role in the global P cycle. The seasonal variation of total $\mathrm{P}(\mathrm{Pt})$ and its fractions along a young soil chronosequence (Hailuogou chronosequence) on the eastern slope of Gongga Mountain, SW China, was investigated based on the modified Hedley fractionation technique to understand $\mathrm{P}$ loss during the early pedogenic stage. The results showed that the apatite-P was the dominant fraction of $\mathrm{Pt}$ in the $\mathrm{C}$ horizon of the soil, and the seasonal difference in $\mathrm{Pt}$ and its fractions was insignificant. In the A horizon, Pt concentrations decreased markedly compared with those in the $\mathrm{C}$ horizon, and as the age of the soil increased, the inorganic $\mathrm{P}(\mathrm{Pi})$ significantly decreased and the organic $\mathrm{P}(\mathrm{Po})$ prominently increased. Seasonally, the $\mathrm{P}$ fractions exhibited various distributions in the A horizon. The variation of $\mathrm{Pt}$ and its fractions revealed that the P loss was rapid along the 120 -year soil chronosequence. The $\mathrm{P}$ stocks in soils $(0-30 \mathrm{~cm})$ started to decrease at the 52 year site. And the $\mathrm{P}$ stock depletion reached almost $17.6 \%$ at the 120 -year site. The loss of $\mathrm{P}$ from the soil of the Hailuogou chronosequence was mainly attributed to weathering, plant uptake, and transport by runoff. About $36 \% \mathrm{P}$ loss was transported into plant biomass $\mathrm{P}$ at the 120 year site. The data obtained indicated that the proglacial chronosequence could be used to elucidate the fast rate of $\mathrm{P}$ loss during the early pedogenic stage. 


\section{Introduction}

Phosphorus $(\mathrm{P})$ is one of the limiting nutrients in diverse natural habitats, including freshwater, marine, and terrestrial biomes (Huang et al., 2013; Elser 2012), especially as nitrogen (N) deposition increases (Elser, et al., 2007; Craine and Jackson, 2010; Cramer, 2010). Mountain regions, especially in some alpine and high-latitude ecosystems where the climate is cold and humid, are the unique terrestrial ecosystems where $\mathrm{P}$ rather than $\mathrm{N}$ becomes the main limiting nutrient (Pérez et al., 2014; Seastedt and Vaccaro, 2001; Wassen et al., 2005). The P limitation in terrestrial ecosystems results from the shortage of bio-available P in the soil (Vitousek et al, 2010). Due to the unique global P cycle (Newman, 1995; Fillippelli, 2008), the content of bioavailable $\mathrm{P}$ in the soil decreases continuously during pedogenesis (Walker and Syers, 1976), resulting in $\mathrm{P}$ becoming the limiting nutrient and ecosystem regression in extreme situations (Walder et al, 2004; Vitousek et al, 2010).

In terrestrial ecosystems, the soil bio-available $\mathrm{P}$ is generally depleted in two ways. One is by $\mathrm{P}$ occlusion over time by biological and geochemical processes in which $\mathrm{P}$ is transformed into stable organic forms (Turner et al., 2007), which are difficult to mineralize (Walker and Syers, 1976). Another is the direct loss of bio-available $\mathrm{P}$ as well as other $\mathrm{P}$ fractions by plant uptake, soil erosion, runoff transport, etc. Compared with other ecosystems, the latter cause of P loss should be more significant in mountain ecosystems due to steep slopes, stronger runoff, and well-developed forests that take up more P. Furthermore, compared with occluding immobilization, the direct loss of $\mathrm{P}$ in mountain regions was almost completely neglected in former studies, and the loss rate and pathway were also far from clear.

Many previous studies found that the total P stock in soils would significantly decrease only after soils had been developed for thousands of years (e.g. Galván-Tejada et al., 2014; Turner et al., 2013; Walker and Syers, 1976). In recently developed soils (younger than one hundred years) where the occluding effect of $\mathrm{P}$ is not as remarkable as in well-developed soil (Zhou et al., 2013; Prietzel et al., 2013), the loss of P has not received enough attention so far. In the Hailuogou chronosequence, soil pH decreased sharply (Zhou et al., 2013) and vegetation succession 
52

developed fast ( $\mathrm{Li}$ and Xiong, 1995) during the initial 120-year pedogenesis. Moreover, the precipitation in this area is rather abundant (mean annual precipitation: $1947 \mathrm{~mm}$ ) (Wu et al., 2013). These factors might lead to a rapid loss of $\mathrm{P}$ in the Hailuogou chronosequence. Therefore, the objective of this study is to know whether and how soil $\mathrm{P}$ was lost during the early pedogenic stage according to the seasonal variation of the concentrations, forms and stocks of $\mathrm{P}$ along this 120-year soil chronosequence. To achieve this objective, soil samples with 6 different ages were collected in the growing and non-growing seasons on the Hailuogou chronosequence. Soil $\mathrm{P}$ forms and relevant properties were measured and soil P loss was calculated based on these samples.

\section{Materials and methods}

\subsection{Study area and samples collection}

Hailuogou Glacier, located on the eastern slope of Gongga Mt., southwestern China (Fig. 1), has been retreating since 1890 ( $\mathrm{Li}$ et al., 2010). A soil chronosequence has developed in the area exposed by the retreat that is approximately $2 \mathrm{~km}$ long, 50-200 m wide and has a $150 \mathrm{~m}$ altitude difference. The soil development on the chronosquence was described by He and Tang (2008). According to the World Reference Base for Soil Classification (2006), the soils are grouped as Regosols. The mineral composition of the parent materials is similar in the retreat area, including plagioclase $(28.5 \%)$, quartz $(24.5 \%)$, biotite $(13.7 \%)$, hornblende $(13.0 \%)$, K-feldspar $(8.6 \%)$ and apatite (1.6\%) (Yang et al., 2015).

Fig. 1 Sketch map of Hailuogou Glacier retreat area and the sampling sites

A complete primary vegetation successional sequence has formed on the chronosequence, including (1) bare land, (2) Salix rehderiana C.K.Schneid. - Hippophae rhamnoides L. - Populus purdomii Rehder, (3) Populus purdomii Rehder, (4) Abies fabri (Mast.) Craib - Picea brachytyla (Franch.) E.Pritz., and (5) Picea brachytyla (Franch.) E.Pritz. - Abies fabri (Mast.) (Li and Xiong, 1995).

The climate on the Hailuogou chronosequence is controlled by the southeast monsoon with a 
mean annual temperature of $4.2^{\circ} \mathrm{C}$ and a mean annual rainfall of $1947 \mathrm{~mm}$ (Wu et al., 2013).

The soil samples were collected in December 2010 and July 2011 at the same plots in each site with different ages after the retreat of the glacier (Fig. 1). Three $2 \times 2 \mathrm{~m}$ plots were created for each site, and the soil profiles were hand-dug at each plot. The soil profiles were divided into three horizons: the $\mathrm{O}, \mathrm{A}$ and $\mathrm{C}$ horizons, except for the 12-year-old site, where the $\mathrm{O}$ and $\mathrm{A}$ horizon were absent.

At each site, the trunk, bark, latest-growth-year leaves and twig were collected and mixed to yield a composite sample from the dominant plants above the soil sampling sites. For each tree, a composite sample was collected from the upper and lower locations on the eastern, southern, western, and northern sides.

\subsection{Chemical analysis}

A modified Hedley fraction extraction technique (Tiessen and Moir 1993) was used to separate the $\mathrm{P}$ into eight fractions (Fig. 2). Two strips of an anion exchange membrane (BDH $551642 \mathrm{~S}, 9 \times 62 \mathrm{~mm}$ ) were put into the tube. The anion exchange membrane strips were converted to bicarbonate before they were used in the first step. The supernatant of Step 1 - 4 was shaken for $16 \mathrm{~h}$ at $25{ }^{\circ} \mathrm{C}$. Thereafter, the supernatant was centrifuged at $25000 \times \mathrm{g}$ for 10 $\min$ at $0{ }^{\circ} \mathrm{C}$, and then passed through Millipore filters (pore size $0.45 \mu \mathrm{m}$ ). The concentrations of the organic $\mathrm{P}(\mathrm{Po})$ were calculated by the differences in the $\mathrm{P}$ concentrations between the undigested and the digested samples. The $\mathrm{P}$ concentrations were measured with a UV-V spectrophotometer (SHIMAZU UV 2450) using the phosphomolybdate blue method (Murphy and Riley, 1962). Blanks were mixed with the solvents to account for matrix interference during the extraction processes. The total $\mathrm{P}(\mathrm{Pt})$ concentration was measured using ICP-AES after subsamples were ground and digested with a microwave $\left(\mathrm{HNO}_{3}-\mathrm{HClO}_{4}-\mathrm{HF}\right)$.

102

The $\mathrm{P}$ fractions were defined as follows: (1) Resin-Pi (RPi, Resin-inorganic $\mathrm{P}$ ) = exchangeable $\mathrm{P}$, (2) $\mathrm{NaHCO}_{3}-\mathrm{P}=$ labile $\mathrm{Pi}$ and $\mathrm{Po}$, (3) NaOH-P = moderately bioavailable $\mathrm{P}$, 
106

107

108

109

110

111

112

113

114

115

116

117

118

119

120

121

122

123

124

125

126

127

128

129

130

131

132

mainly Pi and Po tightly adsorbed and/or fixed by Al and Fe hydroxides, and P in humic and fulvic acids; (4) DHCl-Pi = Pi in primary minerals (mainly apatite); (5) $\mathrm{CHCl}-\mathrm{P}=$ extractable $\mathrm{P}$ by concentrated $\mathrm{HCl}$, refractory P (Tiessen and Moir 1993).

Leaf, trunk, bark and twig were brushed clean and rinsed with deionized water before drying and grinding to a fine powder, respectively. The Pt concentrations of plant samples were measured by ICP-AES after microwave digestion $\left(\mathrm{HNO}_{3}-\mathrm{H}_{2} \mathrm{O}_{2}-\mathrm{HF}\right)$. Values are expressed on a $60^{\circ} \mathrm{C}$ dry-mass basis. The $\mathrm{P}$ concentration of plant samples was reported as the average concentration of leaf, trunk, bark and twig.

\subsection{Estimation of $P$ loss}

Because the largest thickness of A horizons was $<12 \mathrm{~cm}$ in the Hailuogou chronosequence, $\mathrm{P}$ loss in the soils with a depth of $30 \mathrm{~cm}$ was evaluated. The $\mathrm{P}$ loss $\left(\mathrm{P}_{\mathrm{LOSS}}\right)$ was calculated as following equation:

$$
\mathrm{P}_{\text {LOSS }}=\text { Stock- } \mathrm{P}_{\mathrm{C} 30}-\text { Stock-P }
$$

where Stock- $\mathrm{P}_{\mathrm{C} 30}(\mathrm{~kg} / \mathrm{ha})$ is total $\mathrm{P}$ stock in the $\mathrm{C}$ horizon with a thickness of $30 \mathrm{~cm}$ and Stock-P is the sum of $\mathrm{P}$ stock in the $\mathrm{O}$ horizon $\left(\right.$ Stock- $\left.\mathrm{P}_{\mathrm{O}}\right)(\mathrm{kg} / \mathrm{ha})$ and the surface mineral (Stock- $\mathrm{P}_{\mathrm{AC} 30}, 0-$ $30 \mathrm{~cm})(\mathrm{kg} / \mathrm{ha})$ soils.

$$
\begin{aligned}
& \text { Stock- } \mathrm{P}_{\mathrm{C} 30}=\mathrm{C}_{\mathrm{Po}} \times \mathrm{BD}_{\mathrm{o}} \times 30 \div 10 \\
& \text { Stock-P }=\text { Stock- } \mathrm{P}_{\mathrm{O}}+\text { Stock- } \mathrm{P}_{\mathrm{AC} 30} \\
& \text { Stock- } \mathrm{P}_{\mathrm{O}}=\mathrm{C}_{\mathrm{Po}_{0}} \times \mathrm{BD}_{\mathrm{o}} \times \mathrm{D}_{\mathrm{o}} \div 10
\end{aligned}
$$

where $\mathrm{C}_{\mathrm{Po}}(\mathrm{mg} / \mathrm{kg}), \mathrm{BD}_{\mathrm{o}}\left(\mathrm{g} / \mathrm{cm}^{3}\right)$ and $\mathrm{D}_{\mathrm{o}}(\mathrm{cm})$ is the Pt concentration, bulk density and thickness in the $\mathrm{O}$ horizon, respectively.

$$
\text { Stock- } \mathrm{P}_{\mathrm{AC} 30}=\left(\mathrm{C}_{\mathrm{PA}} \times \mathrm{BD}_{\mathrm{A}} \times \mathrm{D}_{\mathrm{A}}+\mathrm{C}_{\mathrm{PC}} \times \mathrm{BD}_{\mathrm{C}} \times\left(30-\mathrm{D}_{\mathrm{A}}\right)\right) \div 10
$$

where $\mathrm{C}_{\mathrm{PA}}(\mathrm{mg} / \mathrm{kg}), \mathrm{BD}_{\mathrm{A}}\left(\mathrm{g} / \mathrm{cm}^{3}\right)$ and $\mathrm{D}_{\mathrm{A}}(\mathrm{cm})$ is the Pt concentration, bulk density and thickness in the A horizon, respectively; $\mathrm{C}_{\mathrm{PC}}(\mathrm{mg} / \mathrm{kg})$ and $\mathrm{BD}_{\mathrm{C}}\left(\mathrm{g} / \mathrm{cm}^{3}\right)$ is the $\mathrm{Pt}$ concentration and bulk density in the $\mathrm{C}$ horizon, respectively.

\section{Results}

The Pt concentrations in the $\mathrm{C}$ horizons across the six sites did not change significantly 
133 (Table 1) and were dominated by the DHCl-Pi, which accounted for $81-97 \%$ of the total P (Fig.

134 3). The seasonal variation in the concentrations of $\mathrm{Pi}, \mathrm{DHCl}-\mathrm{Pi}$ and $\mathrm{Pt}$ and its fractions in the $\mathrm{C}$ 135 horizon was not significant (Fig. 3). The Po always only contributed a small part of Pt in the C 136 horizon (Fig. 3).

137 Both of the Pt concentrations in the $\mathrm{O}$ and A horizons decreased with soil age (Table 1). At 138 the 30-52 years sites, the Pt concentrations in the A horizons were slightly higher than that in the $139 \mathrm{C}$ horizons; while at the 80 and 120 years sites, the Pt concentrations in the $\mathrm{O}$ and $\mathrm{A}$ horizons 140 were significantly lower than those in the $\mathrm{C}$ horizons (Table 1). The average of Pt concentration 141 difference between the $\mathrm{A}$ and $\mathrm{C}$ horizons at the 80 and 120 years sites reached $381 \mathrm{mg} / \mathrm{kg}$ (Table $1421)$.

143 For the $\mathrm{P}$ in the A horizons, the concentrations of Po increased continuously with the age of the soil, while the opposite trend was found for Pi (mainly DHCl-Pi) (Fig. 4). The concentrations of bio-available $\mathrm{P}\left(\mathrm{RPi}+\mathrm{NaHCO}_{3}-\mathrm{P}\right)$ (Tissen and Moir, 1993; Wu et al., 2014), as well as NaOH$\mathrm{P}$, slightly increased with the age of the soil. The significant seasonal difference in the $\mathrm{P}$ fractions was observed for $\mathrm{NaOH}-\mathrm{P}$ and $\mathrm{CHCl}-\mathrm{P}$. The concentrations of $\mathrm{NaOH}-\mathrm{Po}$ in the summer were approximately $100 \mathrm{mg} / \mathrm{kg}$ higher than those in the winter, which was mainly attributed to the increase in the concentration of $\mathrm{NaOH}-\mathrm{Po}$. On the contrary, the concentrations of CHCl-P in the winter were slightly lower than those in the summer, which was mainly related to the low concentration of CHCl-Pi.

Fig. 3 Variations of the concentrations of total $\mathrm{P}$ and its fractions in $\mathrm{C}$ horizon of the Hailuogou chronosequence

Fig. 4 Variation of the concentrations of $\mathrm{P}$ fractions in the A horizons (The concentration of $\mathrm{P}$ in the 12 yrs site was $\mathrm{P}$ in the surface sands $(0-10 \mathrm{~cm})$. $\mathrm{NaHCO}-\mathrm{Pi}$ and $\mathrm{NaHCO}_{3}-\mathrm{Po}$ : inorganic and organic P extracted by $\mathrm{NaHCO}_{3}$ solutions, NaOH-Pi and NaOH-Po: inorganic and organic P extracted by $\mathrm{NaOH}$ solutions, RPi: exchangeable P, DHCl-Pi: apatite P, CHCl-Pi and CHCl-Po: 
160 inorganic and organic $\mathrm{P}$ extracted by concentrated $\mathrm{HCl}, \mathrm{Pa}$ : bioavailable $\mathrm{P}, \mathrm{Pi}$ : inorganic $\mathrm{P}$, Po:

161 organic P, Pt: total P)

1624 Discussion

$163 \quad 4.1$ Was $P$ lost during the 120 years of pedogenesis?

164 The ratios of the Pt concentrations in the A horizon to that in the $\mathrm{C}$ horizon partly revealed 165 the continuous loss of $\mathrm{P}$ with soil age. The ratio of $\mathrm{Pt}_{\mathrm{A}} / \mathrm{Pt}_{\mathrm{C}}$ was 0.62 and 0.74 at the 80 - and 120166 year-old site, respectively. The ratios were much lower than those of the chronosequences of 167 similar soil ages. There were no significant decreases of total $\mathrm{P}$ at the Morteratsch chronosequence (150 years) and the Damma chronosequence (120 years) in the Swiss Alps (Egli et al., 2012; Prietzel et al., 2013). Meanwhile, these ratios were also lower than or similar with those of several older chronosequences. $\mathrm{The}^{\mathrm{Pt}} / \mathrm{Pt}_{\mathrm{C}}$ ratio at the 5000-year-old site of the Franz Josef Chronosequence was approximately 72.7\% (Walker and Syers, 1976). In a dune chronosequence in New Zealand, the ratio at the 370-year-old site was 59.5\% (Eger et al., 2011). There was no obvious change in the total $\mathrm{P}$ at a 7800 -year-old chronosequence in Northern Sweden (Vincent et al., 2013). Lower $\mathrm{Pt}_{\mathrm{A}} / \mathrm{Pt}_{\mathrm{C}}$ ratios implied the severe loss of $\mathrm{Pt}$ in the soil under the climax community, and the loss rate was faster than other soil chronosequences.

The $\mathrm{P}$ stock in the $\mathrm{O}$ horizons and surface mineral soils $(0-30 \mathrm{~cm})$ directly showed the rapid loss of $\mathrm{P}$ on the Hailuogou chronosequence (Table 2). At the 30 and 40 year sites, P loss was not observed; while from the 52 to the 120 year site, the P loss increased with soil age. At the 120 year site, $\sim 17.6 \% \mathrm{Pt}$ in the soils (thickness: $30 \mathrm{~cm}$ ) was lost (Table 2). This is a relative high loss rate compared with other chronosequences with similar or greater ages (Table 2). The P loss rate at the 120 year site on the Hailuogou chronosequence was $\sim 7$ times of that on the Rakata chronosequence, which was $\sim 110$ years old (Table 2 ). Although the P loss rate on the Hailuogou chronosequence was lower than those on some 'old' chronosequences (Table 2), the P loss could not be observed until these 'old' chronosequences had been developed for thousands of years. For example, Galván-Tejada et al. (2014) found that P stocks started to decline after 2185 years of soil development on the Transmexican Volcanic Belt chronosequence. Moreover, Turner et al. 
187 (2013) found that the P stock (TP in soils $<2 \mathrm{~mm}$ ) was $115.0,194.2,169.6$ and $58.0 \mathrm{~g} \mathrm{P} / \mathrm{m}^{2}$ at 188 the 5, 1000, 12000 and 120000 year site on the Franz Josef chronosequence, respectively, suggesting P stock did not decrease sharply at the initial stage of pedogenesis.

\subsection{The pathway of $\mathbf{P}$ loss along the soil chronosequence}

During the early stage of pedogenesis, $\mathrm{P}$ could be released from the parent rocks into the soil by weathering. On the Hailuogou chronosequence, the degree and rate of weathering changed with soil age (Zhou, 2014). The weathering rate at the 120-year-old site was 111 $\mathrm{cmol}_{\mathrm{c}} / \mathrm{m}^{2} \cdot \mathrm{yr}$, which was higher than those in Alps and some tropical zones (Egli et al., 2001; Taylor and Blum, 1995; Neat et al., 2004). The rapid weathering process could lead to the dissolution of apatite bound to carbonates, biotite, hornblende, plagioclase and other silicate minerals. The depletion factor of soil P on the Hailuogou chronosequence demonstrated that only approximately $22 \%$ of the original apatite was remained after 120 years of weathering and pedogenesis (Zhou, 2014). The rapid dissolution of apatite during the weathering process should be ascribed to the fine materials that resulted from strong glaciation and freeze-thaw processes, adequate moisture and sharp decrease of $\mathrm{pH}$ (Zhou et al., 2013) due to rapid vegetation succession.

$\mathrm{P}$ released from minerals as phosphate was available for plant assimilation. Along the Hailuogou chronosequence, the primary vegetation succession was quickly established with the weathering and pedogenesis. The increase of biomass, as well as $\mathrm{P}$ in biomass, was also prominent along the chronosequence (Table 2). The pool of $\mathrm{P}$ in biomass in the forest at the 120 year site was $303.9 \mathrm{~kg} / \mathrm{ha}$, which accounted for $\sim 36 \%$ of P loss (Table 2). Therefore, plant uptake was a significant pathway of P loss from the soil. Moreover, the lower concentrations of bioavailable P in July (Fig. 4), the growing season, confirmed that plant uptake accelerated the loss of $\mathrm{P}$ from the soil.

Besides of the $\mathrm{P}$ assimilated by plant, about $540 \mathrm{~kg} \mathrm{P}$ per ha was lost on the chronosequence. This suggested that in addition to plant uptake, there should be other paths for P loss from the 
213

214

215

216

217

218

219

220

221

222

223

224

225

226

227

228

229

230

231

232

233

234

235

236

237

238

soil on the Hailuogou chronosequence.

Fig. 5 Correlation between $\mathrm{P}$ and $\mathrm{Fe}, \mathrm{Al}$ in the $\mathrm{NaOH}$ extracted solution.

As $\mathrm{P}$ was released from parent rocks, $\mathrm{Fe}, \mathrm{Al}, \mathrm{Ca}$ and other metal ions were released as well during weathering and pedogenesis. Fe and $\mathrm{Al}$ ions were apt to form hydroxides. In addition to being assimilated by plants, the released phosphate tended to be adsorbed onto the surface of Fe and $\mathrm{Al}$ hydroxides. In the $\mathrm{NaOH}$ extracted solutions, the $\mathrm{P}$ concentrations were significantly positively related with Fe and Al concentrations (Fig. 6). This result implied that the P extracted by $\mathrm{NaOH}$ was from $\mathrm{Fe}$ and $\mathrm{Al}$ hydroxides that bound $\mathrm{P}$, which accounts for more than $30 \%$ of the Pt at the 52, 80- and 120-year-old site in December, while it was a little lower in July. A previous study in dark coniferous forests showed that the P bound by $\mathrm{Al}$ and Fe was the major fraction of soil P (Wood et al, 1984). Kaňa and Kopáček (2005) confirmed that the adsorption capacity of $\mathrm{Fe}$ and $\mathrm{Al}$ hydroxides was the dominant factor controlling the transport of soil $\mathrm{P}$ to the water body. Šantrůčková (2004) demonstrated that the lower acidity of the forest soil drove the transformation of $\mathrm{P}$ and changed the $\mathrm{P}$ loss rate. As the vegetation established and evolved on the Hailuogou chronosequence, the soil pH decreased with the soil age (Zhou et al., 2013). In the acidified soils, especially at the 80 - and 120-year-old sites, the P bound by Fe and Al was potentially transported by runoff. The annual precipitation was concentrated in the summer $(\mathrm{Wu}$ et al, 2013). The $\mathrm{P}$ bound by $\mathrm{Fe}$ and $\mathrm{Al}$ could be more significantly discharged by runoff in the summer than in the winter, which could be interpreted as the reason for the lower contribution of $\mathrm{NaOH}-\mathrm{P}$ to the Pt in July than in December. Meanwhile, the elevation difference of $150 \mathrm{~m}$ along less than $2 \mathrm{~km}$ of the Hailuogou chronosequence, led to the strong erosion and great loss of soil P.

The mean concentration of Pt in the Hailuogou glacier waters was $0.049 \pm 0.014 \mathrm{mg} / 1$, according to the Alpine Ecosystem Observation and Experiment Station of Mt. Gongga, Chinese Academy of Sciences (2002-2005). The annual runoff was $307.1 \mathrm{~m}^{3} / \mathrm{yr} \cdot \mathrm{ha}$ in the Hailuogou glacier watershed (Li et al., 2004). The P discharge rate was calculated as $1.5 \mathrm{~kg} \mathrm{P} / \mathrm{yr} \cdot \mathrm{ha}$. 
239

240

241

242

243

244

245

246

247

248

249

250

251

252

253

254

255

256

257

258

259

260

261

262

263

264

265

\section{Conclusion}

During the early stage of pedogenesis at the Hailuogou chronosequence, $\mathrm{P}$ was rapidly lost from the soil. The P loss could be observed after 52 years of deglaciation, and the loss reached $12.9 \%$ and $17.6 \%$ at the 80 - and 120 -year-old site, respectively. The fast loss of $\mathrm{P}$ from the soil could be attributed to the higher weathering rate, the large amount of plant uptake and transport by runoff.

\section{Reference}

Celi L, Cerli C, Turner BL, Santoni S, and Bonifacio E. 2013. Biogeochemical cycling of soil phosphorus during natural revegetation of Pinus sylvestris on disused sand quarries in Northwestern Russia. Plant and Soil 367:121-134. 10.1007/s11104-013-1627-y

Chen CR, Hou EQ, Condron LM, Bacon G, Esfandbod M, Olley J, and Turner BL. 2015. Soil phosphorus fractionation and nutrient dynamics along the Cooloola coastal dune chronosequence, southern Queensland, Australia. Geoderma 257:4-13. 10.1016/j.geoderma.2015.04.027

Craine JM, Jackson RD, 2010. Plant nitrogen and phosphorus limitation in 98 North American grassland soils. Plant Soil, 334 (1-2), 73-84

Cramer MD, 2010. Phosphate as a limiting resource: Introduction. Plant Soil, 334 (1-2), 1-10

Eger A, Almond PC, Condron LM, 2011. Pedogenesis, soil mass balance, phosphorus dynamics and vegetation communities across a Holocene soil chronosequence in a super-humid climate, South Westland, New Zealand. Geoderma, 163(3-4): 185-196

Egli M, Fitze P, Mirabella A, 2001. Weathering and evolution of soils formed on granitic, glacial deposits: results from chronosequences of Swiss alpine environments. Catena, 45(1): 19-47

Egli M, Filip D, Mavris C, Fischer B, Gotze J, Raimondi S, Seibert J, 2012. Rapid transformation of inorganic to organic and plant-available phosphorous in soils of a glacier forefield. Geoderma 189, 215-226

Elser JJ, 2012. Phosphorus: a limiting nutrient for humanity? Current Opinion in Biotechnology, 23: $833-838$ 
266

267

268

269

270

271

272

273

274

275

276

277

278

279

280

281

282

283

284

285

286

287

288

289

290

291

Elser JJ, Bracken MES, Cleland EE, Gruner DS, Harpole WS, Hillebrand H, Ngai JT, Seabloom EW, Shurin JB, Smith JE, 2007. Global analysis of nitrogen and phosphorus limitation of primary production in freshwater, marine, and terrestrial ecosystems. Ecology Letters, $10: 1135-1142$

Fillippelli GM, 2008. The global phosphorus cycle: past, present and future. Elements, 4: 89-95

Galvan-Tejada NC, Pena-Ramirez V, Mora-Palomino L, and Siebe C. 2014. Soil P fractions in a volcanic soil chronosequence of Central Mexico and their relationship to foliar $\mathrm{P}$ in pine trees. Journal of Plant Nutrition and Soil Science 177:792-802. 10.1002/jpln.201300653

He L, Tang Y, 2008. Soil development along primary succession sequences on moraines of Hailuogou Glacier, Gongga Mountain, Sichuan, China. Catena, 72(2): 259-269

Huang WJ, Liu JX, Wang YP, Zhou GY, Han TF, Li Y, 2013. Increasing phosphorus limitation along three successional forests in southern China. Plant Soil 364 (1-2): 181-191

Kaňa J and Kopáček J, 2005. Impact of soil sorption characteristics and bedrock composition on phosphorus concentrations in two Bohemian forest lakes. Water, Air, and Soil Pollution, 173: $243-259$

Li X, Xiong SF, 1995. Vegetation primary succession on glacier foreland in Hailuogou, Mt. Gongga. Mountain Research 12 (2), 109-115 (in Chinese with English abstract)

Li W, Cheng G, Luo J, Lu R, and Liao X. 2004. Features of the natural runoff of Hailuo Ravine in Mt. Gongga. Journal of Mountain Science (Chinese Edition) 22:698-701.

Li ZX, He YQ, Yang XM, Theakstone WH, Jia WX, Pu T, Liu Q, He XZ, Song B, Zhang NN, Wang SJ, Du JK, 2010. Changes of the Hailuogou glacier, Mt. Gongga, China, against the background of climate change during the holocene. Quaternary International 218 (1-2), $166-175$

Luo J, Li W, Liao XY, He ZW, 2004. $\mathrm{CO}_{2}$ emission from soils of the deglaciered region on Hailuogou Glacier in the past 100 years. Journal of Mountain Research, 22: 421-427 (in Chinese with English abstract) 
292 Murphy J, Riley JP, 1962. A modified single solution method for the determination of phosphate in natural waters. Anal Chim Acta 27: 31-36

294

Newman EI, 1995. Phosphorus inputs to terrestrial ecosystems. Journal of Ecology, 83: 713-726

Pérez CA, Aravena JC, Silva WA, Enriquez JM, Farina JM, and Armesto JJ. 2014. Ecosystem development in short-term postglacial chronosequences: $\mathrm{N}$ and $\mathrm{P}$ limitation in glacier forelands from Santa Ines Island, Magellan Strait. Austral Ecology 39:288-303. $10.1111 /$ aec. 12078

Prietzel J, Dumig A, Wu YH, Zhou J, Klysubun W, 2013. Synchrotron-based P K-edge XANES spectroscopy reveals rapid changes of phosphorus speciation in the topsoil of two glacier foreland chronosequences. Geochimica et Cosmochimica Acta, 108: 154-171

Šantrůčková H, Vrba J, Pieck T, Kopáček J, 2004. Soil biochemical activity and phosphorus transformations and losses from acidified forest soils. Soil Biology \& Biochemistry 36: $1569-1576$

Schlesinger WH, Bruijnzeel LA, Bush MB, Klein EM, Mace KA, Raikes JA, and Whittaker RJ. 1998. The biogeochemistry of phosphorus after the first century of soil development on Rakata Island, Krakatau, Indonesia. Biogeochemistry 40:37-55. Doi 10.1023/A:1005838929706

Seastedt, TR, Vaccaro, L, 2001. Plant species richness, productivity, and nitrogen and phosphorus limitations across a snowpack gradient in alpine tundra, Colorado, USA. Arct Antarct Alp Res, 33 (1), 100-106

Taylor A, Blum JD, 1995. Relation between Soil Age and Silicate Weathering Rates Determined from the Chemical Evolution of a Glacial Chronosequence. Geology, 23(11): 979-982

Tiessen H, Moir JO, 1993. Characterization of available P by sequential extraction. In: C MR (ed) Soil Sampling and Methods of Analysis. Lewis Publishers

Turner BL, Condron LM, Richardson SJ, Peltzer DA, and Allison VJ. 2007. Soil organic phosphorus transformations during pedogenesis. Ecosystems 10:1166-1181. 10.1007/s10021-007-9086-z 
319 Turner BL, and Laliberte E. 2015. Soil development and nutrient availability along a 2 million-

320 year coastal dune chronosequence under species-rich Mediterranean shrubland in

321 Southwestern Australia. Ecosystems 18:287-309. 10.1007/s10021-014-9830-0

322 Turner BL, Lamber H, Condron LM. Cramer MD, Leake JR, Richardson AE, Smith SE, 2013.

323 Soil microbial biomass and the fate of phosphorus during long-term ecosystem development.

$324 \quad$ Plant Soil, 367:225-234

325 Vincent, A.G., Vestergren, J., Grobner, G., Persson, P., Schleucher, J., Giesler, R., 2013. Soil organic phosphorus transformations in a boreal forest chronosequence. Plant Soil 367(1-2), $149-162$

Vitousek, PM, Porder, S, Houlton, BZ, Chadwick, OA, 2010. Terrestrial phosphorus limitation: Mechanisms, implications, and nitrogen-phosphorus interactions. Ecol Appl, 20 (1), 5-15

Walder DA, Walker LR, and Bardgett RD, 2004. Ecosystem properties and forest decline in constrasting longterm chronosequences. Science, 305: 509-513

Walker TW and Syers JK, 1976. The fate of phosphorus during pedogenesis. Geoderma, 15: 119

Wassen, M.J., Venterink, H.O., Lapshina, E.D., Tanneberger, F., 2005. Endangered plants persist under phosphorus limitation. Nature, 437 (7058), 547-550

Wood T, Bormann FH, Voigt GK, 1984. Phosphorus cycling in an Northern Hardwood Forest: biological and chemical control. Science 223: 391-393

Wu YH, Li W, Zhou J, Cao Y, 2013. Temperature and precipitation variations at two meteorological stations on eastern slope of Gongga Mountain, SW China in the past two decades. Journal of Mountain Science 10: 370-377

Wu YH, Prietzel J, Zhou J, Bing HJ, Luo J, Yu D, Sun SQ, Liang JH, Sun HY, 2014. Soil phosphorus bioavailability assessed by XANES and Hedley sequential fraction technique in a glacier foreland chronosequence in Gongga Mountain, Southwestern China. Science in China (Series D), 57(8): 1860-1868 
345 Yang ZJ, Bing HJ, Zhou J, Wu YH, Sun HY, Luo J, Sun SQ, Wang JP, 2015. Variation of 346 mineral composition along the soil chronosequence at the Hailuogou glacier foreland of 347 Gongga Mountain. Acta Pedologica Sinica 52 (3): 39-48 (in Chinese with English abstract)

348 Zhou J, Wu YH, Prietzel J, Bing HJ, Yu D, Sun SQ, Luo J, Sun HY, 2013. Changes of Soil 349 phosphorus speciation along a 120-year soil choronosequence in the Hailuogou Glacier 350 retreat area (Gongga Mountain, SW China). Geoderma, 195-196: 251-259

351 Jun Zhou, 2014. Weathering, pedogenesis and changes of soil phosphorus speciation of 352 Hailuogou Glacier foreland chronosequence. (unpublished dissertation) 


\section{Table $\mathbf{1}$ (on next page)}

Total P concentrations and soil properties along the Hailuogou chronosequence 
2 Table 1 Total P concentrations and soil properties along the Hailuogou chronosequence

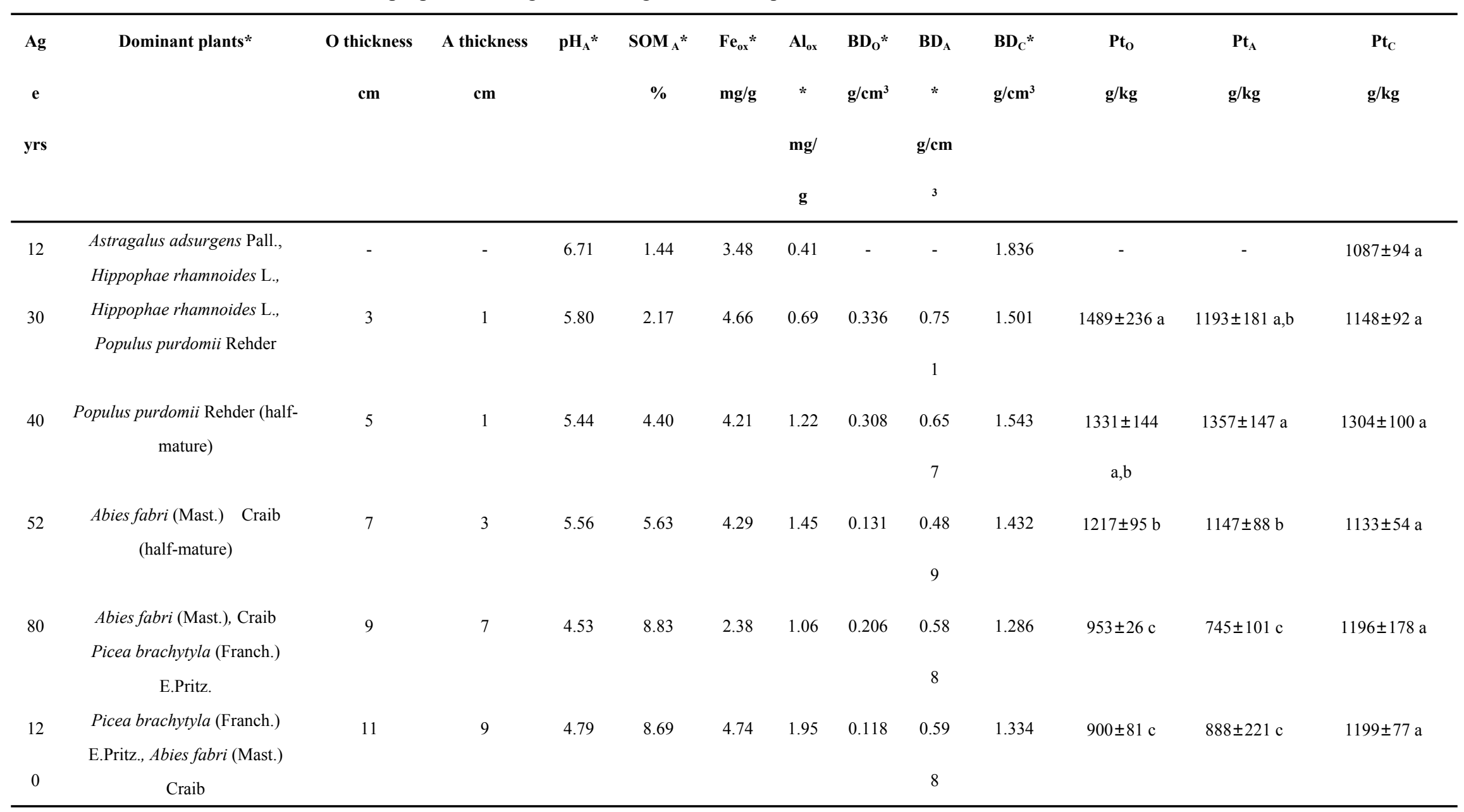

$3 \mathrm{O}$ thickness and A thickness: the thickness of the $\mathrm{O}$ and A horizon. The thickness was reported using an average value of six profiles at each site (three $4 \quad$ profiles in 2010 and 2011, respectively).

5 *: The data were from Zhou et al. (2013). $\mathrm{BD}_{\mathrm{O}}, \mathrm{BD}_{\mathrm{A}}$ and $\mathrm{BD}_{\mathrm{C}}$ : soil bulk density in the $\mathrm{O}, \mathrm{A}$ and $\mathrm{C}$ horizon. $\mathrm{The}_{\mathrm{pH}}, \mathrm{SOM}_{\mathrm{A}}, \mathrm{Fe}_{\mathrm{ox}}$ and $\mathrm{Al}_{\mathrm{ox}}$ represents $\mathrm{pH}$, 
soil organic matter, amorphous $\mathrm{Fe}$ and $\mathrm{Al}$ in the $\mathrm{A}$ horizons, respectively.

$\mathrm{Pt}_{\mathrm{O}}, \mathrm{Pt}_{\mathrm{A}}$ and $\mathrm{Pt}_{\mathrm{C}}$ : concentrations of total $\mathrm{P}$ in the $\mathrm{O}, \mathrm{A}$ and $\mathrm{C}$ horizon. The $\mathrm{P}$ concentrations was reported using an average concentration in December 2010 and July 2011 (mean \pm SD, $n=6$ ). Different letters indicate significantly different variables between different stages at the $p<0.05$ level. 


\section{Table 2 (on next page)}

Comparison of biomass, biomass P pool and P stock between the Hailuogou and other chronosequences 
1 Table 2 comparison of biomass, biomass P pool and P stock between the Hailuogou and other chronosequences

\begin{tabular}{|c|c|c|c|c|c|c|c|c|c|c|c|c|}
\hline No. & $\begin{array}{l}\text { Age } \\
\text { yrs }\end{array}$ & Site & $\begin{array}{c}\text { Biomass }^{a} \\
\text { t/ha }\end{array}$ & $\begin{array}{l}\mathbf{P}_{\text {plant }}{ }^{\mathrm{b}} \\
\mathrm{g} / \mathrm{kg}\end{array}$ & $\begin{array}{c}\text { Biomass P } \\
\text { kg/ha }\end{array}$ & $\begin{array}{c}\text { Stock-P } \\
\text { kg/ha }\end{array}$ & $\begin{array}{c}\text { Stock-P }{ }_{\mathrm{AC} 30} \\
\mathrm{~kg} / \mathrm{ha}\end{array}$ & $\begin{array}{c}\text { Stock-P } \\
\text { kg/ha }\end{array}$ & $\begin{array}{c}\text { Stock-P } \mathbf{P}_{\mathrm{C} 30} \\
\mathrm{~kg} / \mathrm{ha}\end{array}$ & $\begin{array}{c}\mathbf{P}_{\text {Loss }} \\
\text { Kg/ha }\end{array}$ & $\begin{array}{c}\mathbf{P}_{\text {Loss }} / \text { Stock-P } \\
\% \\
\%\end{array}$ & Source \\
\hline \multirow{5}{*}{1} & 12 & Hailuogou & 3.1 & 1.6 & 5.0 & N.D. & 5988 & 5988 & 5988 & 0 & 0.0 & This study \\
\hline & 40 & Hailuogou & 110.8 & 0.9 & 99.7 & 205 & 5924 & 6129 & 6036 & -93 & -1.5 & This study \\
\hline & 52 & Hailuogou & 184.7 & 0.9 & 164.9 & 112 & 4548 & 4659 & 4866 & 207 & 4.3 & This study \\
\hline & 80 & Hailuogou & 308.0 & 0.7 & 225.2 & 177 & 3845 & 4021 & 4615 & 593 & 12.9 & This study \\
\hline & 120 & Hailuogou & 382.3 & 0.8 & 303.9 & 117 & 3836 & 3953 & 4798 & 845 & 17.6 & This study \\
\hline 2 & 40 & Maluxa & & & & 23 & 910 & 933 & 816 & -117 & -14.3 & Celi et al., 2013 \\
\hline 3 & 98 & Morteratsch & & & & N.D. & 1122 & 1122 & 1046 & -75 & -7.2 & Egli et al., 2012 \\
\hline 4 & 110 & Rakata & & & & N.D. & 1129 & 1129 & 1157 & 28 & 2.4 & Schlesinger et al., 1998 \\
\hline 5 & 6500 & S. Westland & & & & N.D. & 487 & 487 & 1822 & 1335 & 73.3 & Eger et al., 2011 \\
\hline 6 & $\sim 3200$ & Cooloola & $P_{\text {LOsS }}$ is the $d$ & ence of $P$ & ks between 4 & $\mathrm{~d} \sim 3200 \mathrm{yrs}$ & $400 \mathrm{yrs}: 260 \mathrm{~kg}$ & , $\sim 3200 \mathrm{yrs}$ & $9 \mathrm{~kg} \mathrm{P} / \mathrm{ha}$. & 141 & 54.2 & Chen et al., 2015 \\
\hline 7 & & & $\mathrm{P} / \mathrm{ha}$. & & & & & & & & & 2015 \\
\hline 8 & 120000 & Franz Josef & $P_{\text {Loss }}$ is the $d$ & ence of $\mathrm{P}$ & ks between 5 & $1.2 \times 10^{5} \mathrm{yrs}$ & 5 yrs: $1150 \mathrm{~kg}$ & $1.2 \times 10^{5} \mathrm{y}$ & $80 \mathrm{~kg} \mathrm{P} / \mathrm{ha}$. & 570 & 49.6 & Turner et al., 2013 \\
\hline \multirow[t]{2}{*}{9} & $>100000$ & Transmexican & P stocks decl & after 218 & of soil devel & & & & & & & Galván-Tejada et al., \\
\hline & & Volcanic Belt & & & & & & & & & & 2014 \\
\hline
\end{tabular}

\footnotetext{
2 a: Biomass was the sum of above and below ground calculated according to Luo et al (2004). b: the P concentration was the average concentration of leaf,

3 trunk, bark and twig.

4 Stock- $\mathrm{P}_{\mathrm{O}}$ : $\mathrm{P}$ stock in the $\mathrm{O}$ layer

5 Stock- $\mathrm{P}_{\mathrm{AC} 30}$ : total $\mathrm{P}$ stock in the surface mineral soils (depth: $0-30 \mathrm{~cm}$ ).

6 Stock-P: Stock- $\mathrm{P}_{\mathrm{O}+}$ Stock-P $\mathrm{P}_{\mathrm{AC} 30}$

7 Stock- $\mathrm{P}_{\mathrm{C} 30}$ : total $\mathrm{P}$ stock in the $\mathrm{C}$ horizon with a thickness of $30 \mathrm{~cm}$.

8 P $\mathrm{P}_{\text {Loss }}$ : Stock- $\mathrm{P}_{\mathrm{C} 30}$ - Stock-P
} 
1

Sketch map of Hailuogou Glacier retreat area and the sampling sites mparis

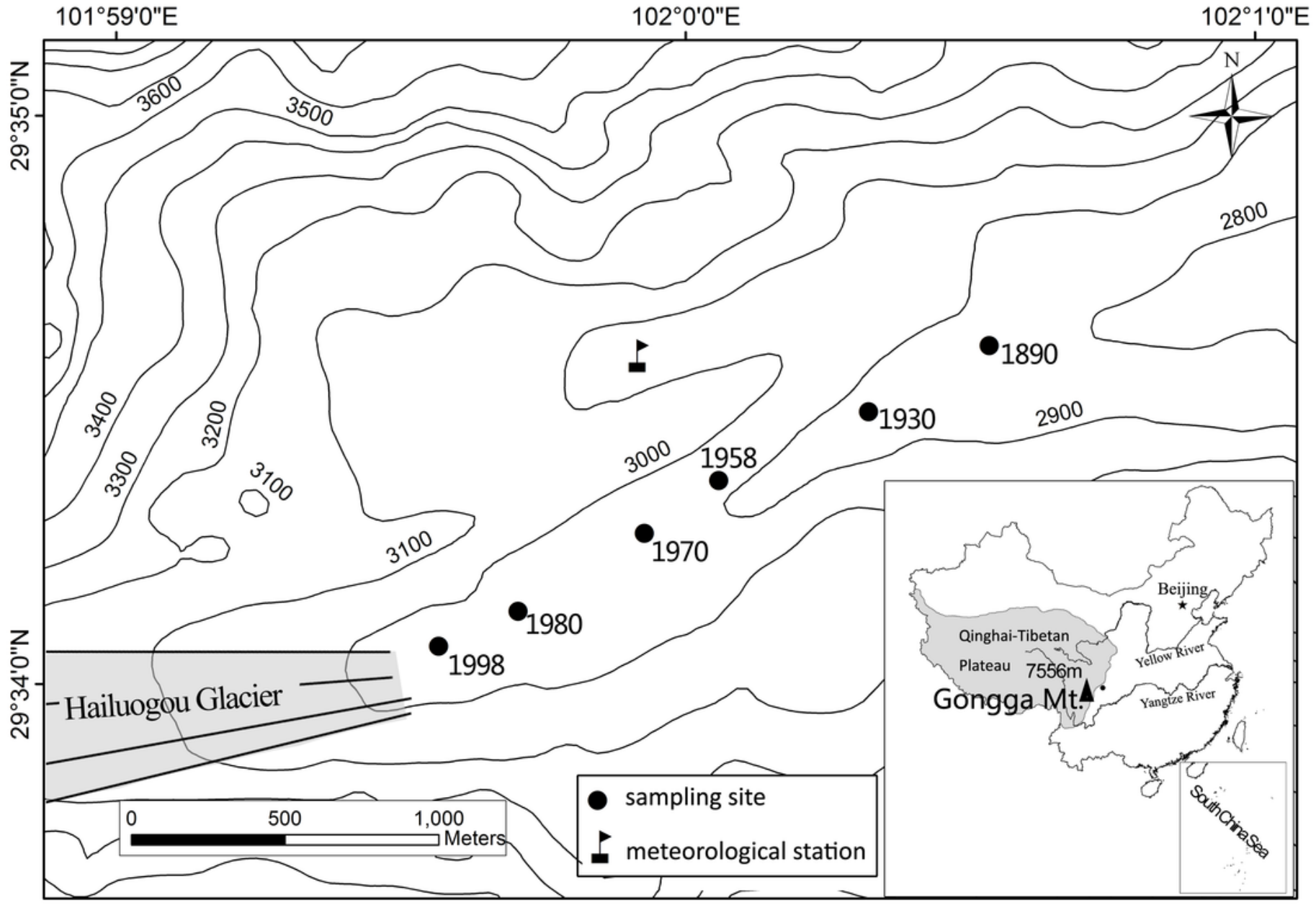


2

The extraction procedure of $\mathrm{P}$ in soil (modified from Tiessen and Moir, 1993)

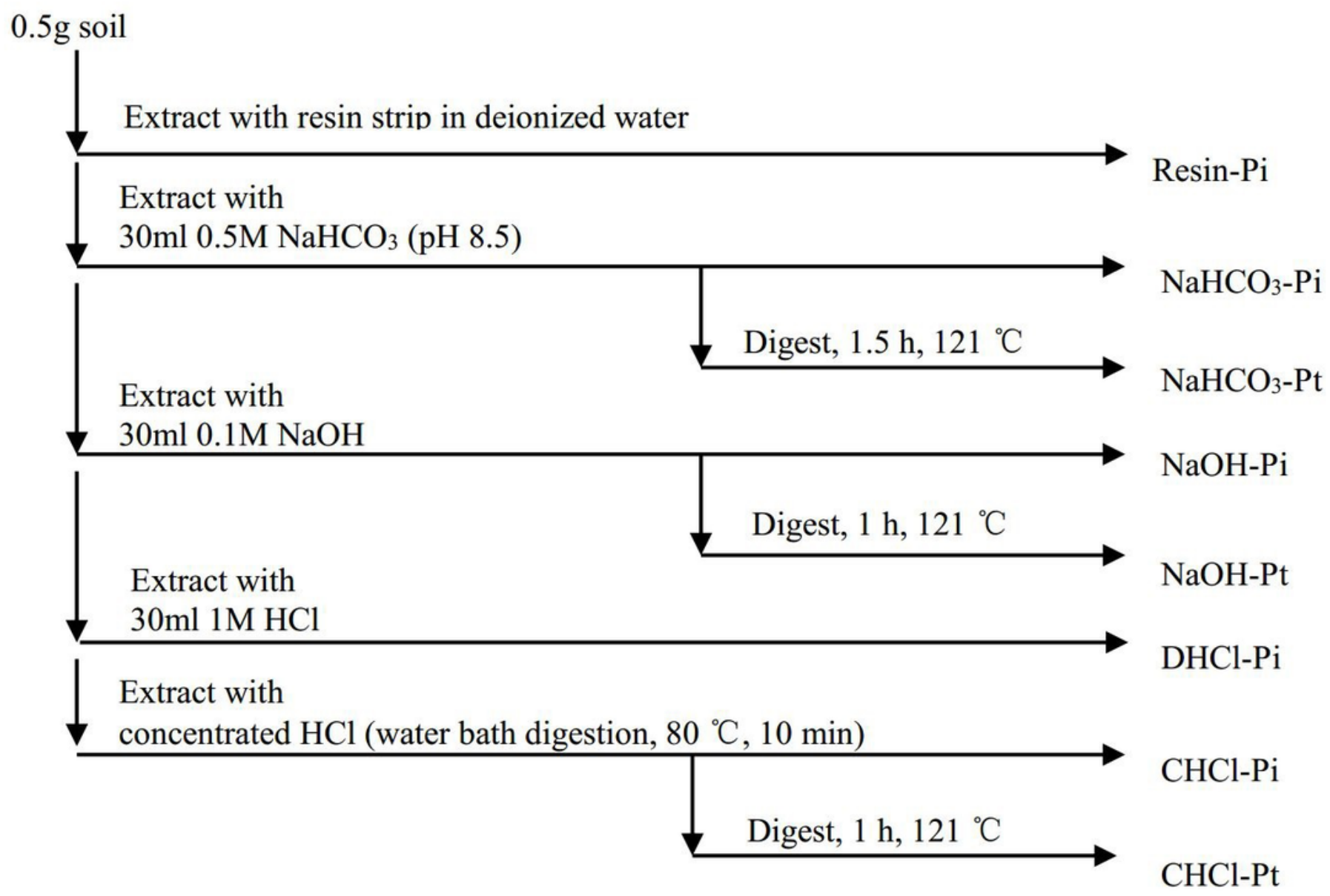


3

Variations of the concentrations of total P and its fractions in C horizon of the Hailuogou chronosequence
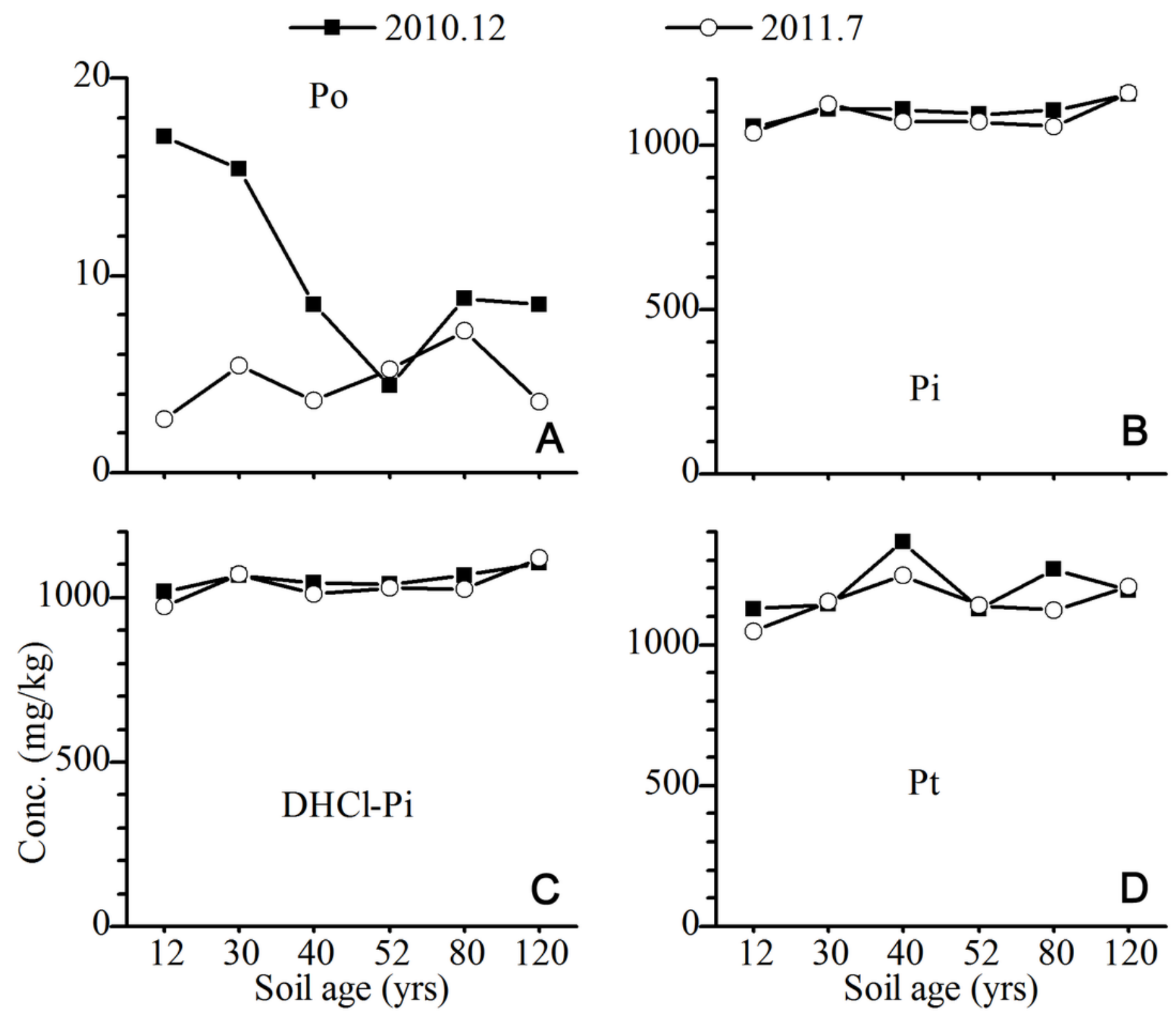
4

Variation of the concentrations of $\mathrm{P}$ fractions in the $\mathrm{A}$ horizons (The concentration of $\mathrm{P}$ in the 12 yrs site was $P$ in the surface sands $(0-10 \mathrm{~cm})$.

NaHCO3-Pi and $\mathrm{NaHCO}_{3}-\mathrm{Po}$ : inorganic and organic $\mathrm{P}$ extracted by $\mathrm{NaHCO}_{3}$ solutions, $\mathrm{NaOH}-\mathrm{Pi}$ and $\mathrm{NaOH}-\mathrm{Po}$ : inorganic and organic $\mathrm{P}$ extracted by $\mathrm{NaOH}$ solutions, RPi: exchangeable $\mathrm{P}$, DHCl-Pi: apatite $\mathrm{P}, \mathrm{CHCl}-\mathrm{Pi}$ and $\mathrm{CHCl}-\mathrm{Po}$ : inorganic and organic $\mathrm{P}$ extracted by concentrated $\mathrm{HCl}, \mathrm{Pa}$ : bioavailable $\mathrm{P}, \mathrm{Pi}$ : inorganic $\mathrm{P}, \mathrm{Po}$ : organic $\mathrm{P}, \mathrm{Pt}$ : total P)
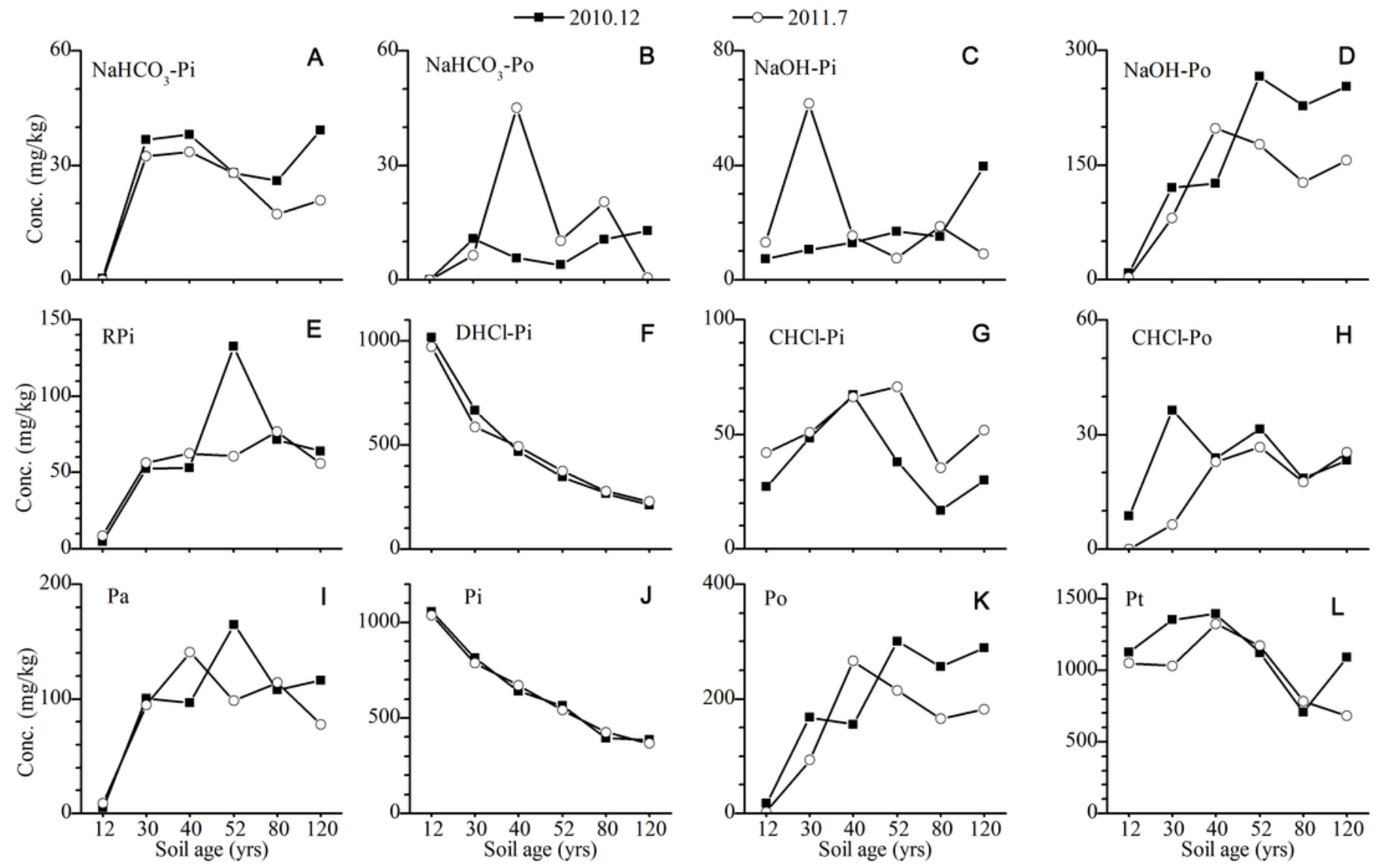
5

Correlation between $\mathrm{P}$ and $\mathrm{Fe}, \mathrm{Al}$ in the $\mathrm{NaOH}$ extracted solution.
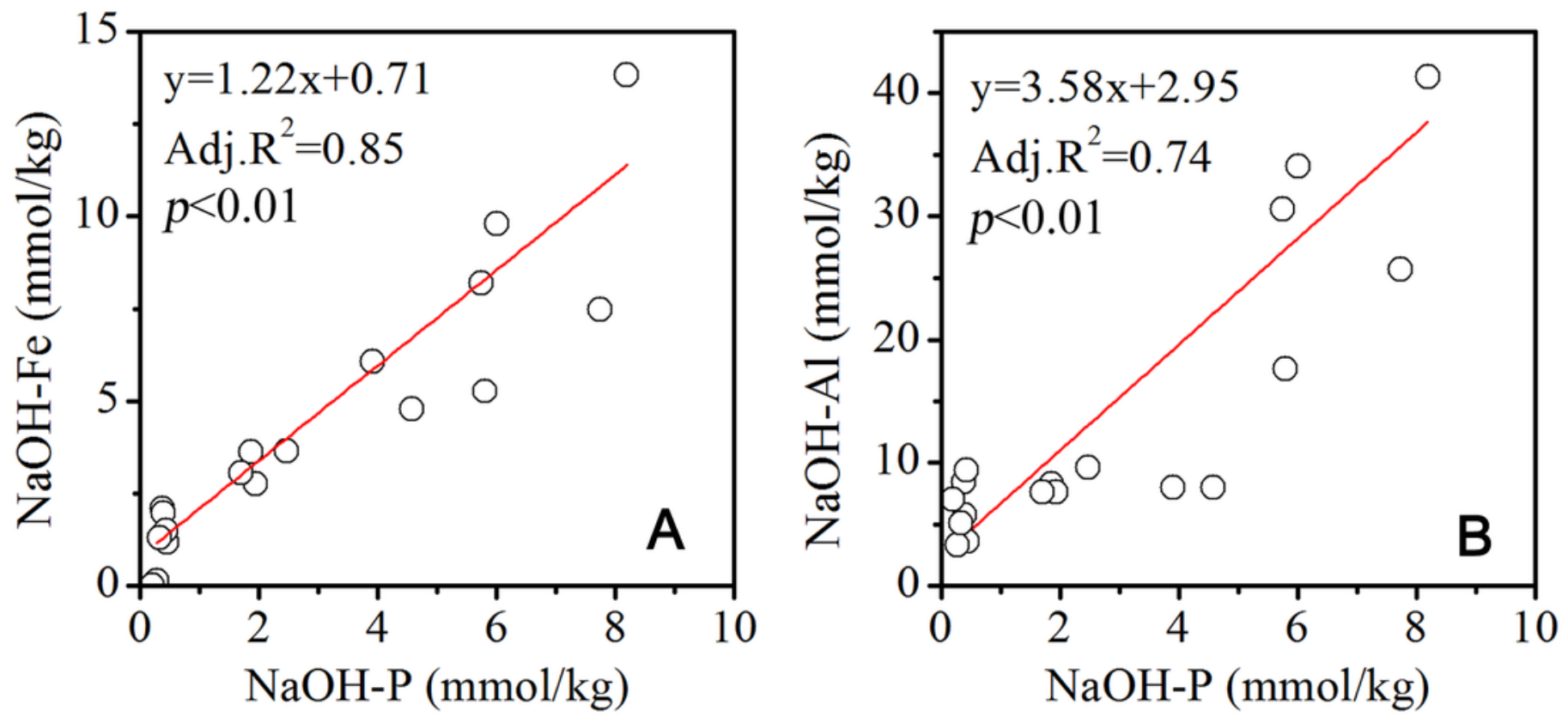